\title{
Nutritional effects of Artemia from different locations on larval development of crabs
}

\author{
C. G. Bookhout and J. D. Costlow, Jr. \\ Duke University Marine Laboratory; Beaufort, North Carolina, USA
}

\begin{abstract}
EXTRAIT: Effets nutrionnels des Artemia de diverses localités sur le développement larvaire des crabes. Quatre espèces de crabes ont été élevées avec des Artemia salina (L.) des étangs salés de Californie et du Great Salt Lake, Utah, pour déterminer s'il existe des différences dans le développement et la survie se rapportant aux deux sources de nourriture. Les Rhithropanopeus harrisii (Gould) ont très bien survecu jusqu'au stade mégalope avec les nauplii d'Artemia des deux localités. Ceux qui ont été nourris avec les nauplii d'Artemia de Californie se sont normalement développés et 94 à $98 \%$ du nombre total de zoés sont allés jusqu'au premier stade crabe. Ceux qui ont été nourris avec les nauplii d'Artemia d'Utah ont un stade mégalope anormal et aucun d'entre eux n'atteint le premier stade crabe. Les nauplii des Artemia d'Utah ont un effect nuisible à la fois sur les stades zoé et mégalope d'Hexapanopeus angustifrons (BenEDict \& RathBUN) et aucun n'atteint le premier stade crabe. Soixante neuf pour cent des larves des crabes qui ont été nourries avec les nauplii de Californie ont survécu jusqu'au premier stade crabe. La survie jusqu'au stade mégalope fut très élevée chez les zoés de Libinia emarginata LEACH nourries à la fois avec les Artemia de Californie et d'Utah, mais seulement $5 \%$, nourries avec les Artemia d'Utah, ont survécu en comparaison des $63 \%$ des larves qui ont été nourries avec les Artemia de Californie. Les larves de Callinectes sapidus RaTHBun ont montré des différences dans le taux de survie en faveur des nauplii d'Artemia de Californie mais elles ne sont pas importantes. Des explications possibles relatives aux anormalités du développement et aux différences de survie sont discutées en rapport avec ces différences dans les proportions, du DDT a été trouvé dans les Artemia de Californie et d'Utah.
\end{abstract}

\section{INTRODUCTION}

Kuenen (1939) wrote a comprehensive article on the systematics and variability of Artemia, the brine shrimp, from various locations in the world. He concluded that the results of scientists working on brine shrimp from different localities often varied because of differences in the source of material, more than because of different circumstances under which the experiments were conducted. He found that the California Artemia from Monterey differed from the brine shrimp from the salt works near Caglairi, Sardinia, in reaction to external stimuli, cellular and nuclear size, and in reproductive organs. He could not cross the California and Italian animals. Tentatively, he concluded that Artemia salina, as previously understood, is not one species. He suggests that two species might be distinguished:

(1) Artemia salina (L) - Cancer salinus LinNé, 1758, which has two lateral hairs on each abdominal segment, and 
(2) Artemia gracilis VERRILL, 1869, with no such hairs on the abdomen.

VERRILI's original description of Artemia gracilis was based on material from Utah. It agreed with the characteristics of brine shrimp KuENEN (1939) studied from California and from Molla Kary near the Caspian Sea. Kunnen advised that the second species not be adopted until the question is solved with more certainty.

Rollefsen (1939) discovered that Artemia nauplii were satisfactory food for post-larval plaice, flounder and cod. In subsequent years they have been used widely by numerous investigators throughout the world for rearing fish, shrimp, hermit crabs, and crabs. They are also used extensively for various types of physiological and biochemical studies.

Despite the warning by KUENEN (1939) that Artemia from different geographical locations may give different experimental results, most investigators fail to mention the source of Artemia used in experiments. Hence, comparison and verification of results of different authors is difficult.

Until 1966 we used Artemia eggs from a supplier in San Francisco who obtained his eggs from salt pools in California, and we found the newly hatched nauplii to be ideal food for crab zoeae. When the San Francisco dealer went out of business, Artemia eggs had to be procured from another supplier who obtained Artemia eggs from Great Salt Lake, Utah. The survival rates of various species of crabs took a marked drop with the use of Artemia eggs from Utah. The larvae would usually survive through zoeal stages to megalopa, but died in the latter stage. LITTLE (1969) also reported that Palaemon macrodactylus could be reared on San Francisco Bay Artemia nauplii, but not on Artemia nauplii from Great Salt Lake, Utah.

Early in 1967 we were again able to obtain Artemia eggs from California. Hence, in the summer of 1967 , Rbitbropanopeus harrisii (Gould), Hexapanopeus angustifrons (BENEDICT \& RATHBUN), Libinia emarginata LEACH and Callinectes sapidus RATHBUN were reared on Artemia salina (L) nauplii from California salt pools and Great Salt Lake, Utah, to determine if there are any differences in development and survival related to the two sources of food. If there are differences, are there any clues as to why Artemia nauplii from different locations give different results?

\section{METHODS}

Ovigerous Rbitbropanopeus barrisiz and Hexapanopeus angustifrons, small mud crabs belonging to the family Xanthidae, were collected in the Newport River estuary in the vicinity of Beaufort, North Carolina. Ovigerous Libinia emarginata and Callinectes sapidus were obtained outside the Beaufort Inlet.

The small mud crabs, $R$. harrisii and $H$. angustifrons, were placed in finger bowls containing seawater of $25 \%$ and $30 \%$ respectively, the salinities to be used during rearing of larvae. They were maintained in a culture cabinet at $25^{\circ} \mathrm{C}$ until the larvae hatched. These salinities and temperatures were used because they had previously been found to be close to optimum for rearing $R$. barrisii (CostLow et al. 1966) and $H$. angustifrons (Costlow \& Bookhout 1966). 
The method for developing the eggs of Libinia emarginata and Callinectes sapidus was the same as Costrow \& BookHout described in 1960. Pleopods bearing eggs were removed, placed in finger bowls of seawater at $35 \%$ for L. emarginata and $30 \%$ for C. sapidus, the salinities to be used for rearing the larvae. Strands of eggs were cut with fine scissors from pleopods. The eggs were further dissociated, with glass needles, into groups of 100-1000 and transferred to freshly filtered seawater. The eggs were washed in a third bowl and then placed in compartments of plastic boxes containing approximately $20 \mathrm{ml}$ of filtered seawater. The compartmented boxes were placed on an EBERBACH variable-speed shaker and the assembly was kept in a culture cabinet at $25^{\circ} \mathrm{C}$.

When hatching occurred, the first stage zoeae of the four species of crabs were segregated to Carolina finger bowls, $88 \mathrm{~mm}$ in diameter, 10 zoeae per bowl. As shown in Tables 1, 2, 3 and 4, duplicate series of larvae were maintained from a single female of each species; one series was fed freshly hatched Artemia nauplii from Utah and the other given Artemia nauplii from California. The amount of food supplied each bowl per day was one concentrated drop of Artemia nauplii. (In the remainder of the text when Artemia is mentioned it will mean freshly hatched Artemia nauplii.)

Each day the bowls were examined for the number of crab larvae alive, the number dead, and the number of molts. Immediately afterwards the larvae were transferred to clean bowls of filtered sea water, were fed, and returned to culture cabinets. When a zoea molted into a megalopa, it was placed into one of the compartments of a plastic box. Megalopa were transferred daily to clean, compartmented boxes.

Brine shrimp nauplii, hatched from eggs from Great Salt Lake, Utah, and from eggs from salt pools near San Francisco Bay, California, were analyzed for pesticides by the Southern Testing and Research Laboratories, Wilson, North Carolina, U.S.A. The following methods were used. Each sample was extracted with water and acetonitrile using a high speed blender. Pesticides were removed from the extraction mixture by shaking with petroleum ether. The petroleum ether containing the pesticides was placed on a chromatographic column of florisil. The pesticides were eluted from the column by: (1) $6 \%$ ethyl ether in petroleum ether and (2) $15 \%$ ethyl ether in petroleum ether. These separate elutions were then evaporated to a suitable volume for injection into a gas chromatograph.

\section{RESULTS}

In the small mud crab, Rbithropanopeus harrisii, survival to megalopa was equally good, $95 \%$ to $100 \%$ on California and Utah Artemia. Normality of the megalopa, however, and further development differed markedly. Those fed on California Artemia developed into normal megalopa (Fig. 1) and $94 \%$ to $98 \%$ of them went to the first crab stage (Tab. 1). In the Utah-fed series, the megalopa were abnormal in that the legs projected backwards in an extended condition (Fig. 2) and none of them reached the first crab stage. 
When the narrow mud crab, Hexapanopeus angustifrons, was reared on California Artemia, $74 \%$ reached the megalopal stage and $69 \%$ molted to the first crab stage (Tab. 2). When they were reared on Utah Artemia only $10 \%$ reached the
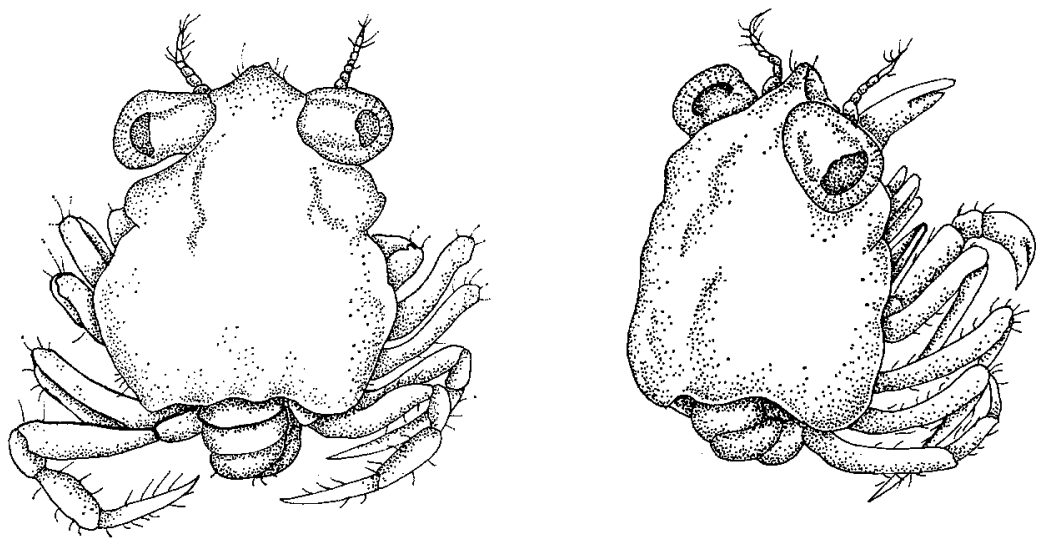

\section{$\stackrel{\square}{0.19 \mathrm{~mm}}$}

Fig. 1: Normal megalopa of Rhitbropanopeus harrisii reared on California Artemia nauplii
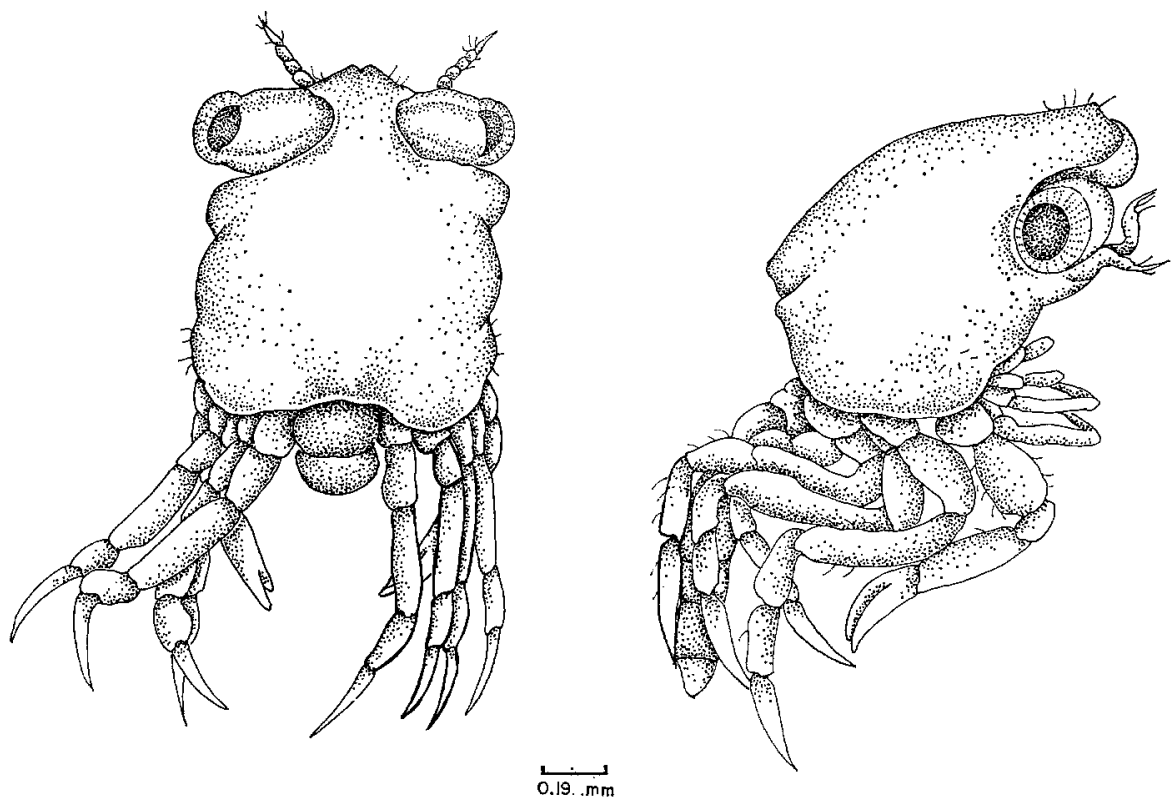

Fig. 2: Abnormal megalopa of Rhitbropanopeus harrisii reared on Utah Artemia nauplii

megalopal stage and $2 \%$ of these were abnormal. Apparently, Artemia from Utah had a detrimental effect on both zoeal and megalopal stages. No megalopa reached the first crab stage. 
The large spider crab, Libinia emarginata, passes through two zoeal stages and a megalopal stage before molting to the first crab stage. Survival to the megalopal stage was high in the zoeae fed on both the California and Utah Artemia, but

Table 1

Comparison of survival and normality of Rhithropanopeus harrisii larvae fed on Artemia nauplii from California and from Utah

(Rbitbropanopeus harrisii: salinity $25 \%$, temperature $25^{\circ} \mathrm{C}$ )

\begin{tabular}{|lccrrrrrc|}
\hline $\begin{array}{l}\text { Source of } \\
\text { Artemia }\end{array}$ & Crab & $\begin{array}{c}\text { Original } \\
\text { number } \\
\text { of zoeae }\end{array}$ & $\begin{array}{c}\text { Number of } \\
\text { megalopa } \\
\text { norm. }\end{array}$ & $\begin{array}{c}\text { Number } \\
\text { deform. }\end{array}$ & $\begin{array}{c}\text { Num crabs } \\
\text { of }\end{array}$ & $\begin{array}{c}\text { Days to } \\
\text { megalopa }\end{array}$ & $\begin{array}{c}\text { Days to } \\
\text { 1st crab }\end{array}$ \\
\hline California & 1 & 100 & 100 & 0 & 98 & - & 10.0 & 4.75 \\
California & 2 & 100 & 97 & 0 & 94 & - & 10.1 & 5.4 \\
Utah & 1 & 100 & 0 & 98 & 0 & - & 9.91 & - \\
Utah & 1 & 100 & 0 & 99 & 0 & - & 10.1 & - \\
Utah & 2 & 100 & 0 & 98 & 0 & - & 10.62 & - \\
Utah & 2 & 100 & 1 & 95 & 0 & - & 10.4 & - \\
\hline
\end{tabular}

Table 2

Comparison of survival and normality of Hexapanopeus angustifrons larvae fed on Artemia nauplii from California and from Utah

(Hexapanopeus angustifrons: salinity $30 \%$, temperature $25^{\circ} \mathrm{C}$ )

\begin{tabular}{|lccrrrrrr|}
\hline $\begin{array}{l}\text { Source of } \\
\text { Artemia }\end{array}$ & Crab & $\begin{array}{c}\text { Original } \\
\text { number } \\
\text { of zoeae }\end{array}$ & $\begin{array}{c}\text { Number of } \\
\text { megalopa } \\
\text { norm. } \\
\text { deform. }\end{array}$ & $\begin{array}{c}\text { Number } \\
\text { of crabs } \\
\text { norm. }\end{array}$ & $\begin{array}{c}\text { Days to } \\
\text { deform. }\end{array}$ & $\begin{array}{c}\text { Days to } \\
\text { megalopa }\end{array}$ & 1st crab \\
\hline $\begin{array}{l}\text { California } \\
\text { Utah }\end{array}$ & 1 & 100 & 74 & 0 & 69 & - & 14.21 & 7.27 \\
\hline
\end{tabular}

Table 3

Comparison of survival of Libinia emarginata larvae fed on Artemia nauplii from California and from Utah

(Libinia emarginata: salinity $35 \%$, temperature $25^{\circ} \mathrm{C}$ )

\begin{tabular}{|lcccccccc|}
\hline $\begin{array}{l}\text { Source of } \\
\text { Artemia }\end{array}$ & Crab & $\begin{array}{c}\text { Original } \\
\text { number } \\
\text { of zoeae }\end{array}$ & $\begin{array}{c}\text { Number of } \\
\text { megalopa } \\
\text { norm. } \\
\text { deform. }\end{array}$ & $\begin{array}{c}\text { Number } \\
\text { of crabs } \\
\text { norm. }\end{array}$ & $\begin{array}{c}\text { Days to } \\
\text { megalopa }\end{array}$ & $\begin{array}{c}\text { Days to } \\
\text { 1st crab }\end{array}$ \\
\hline $\begin{array}{l}\text { California } \\
\text { Utah }\end{array}$ & 1 & 100 & 95 & 0 & 63 & - & 7.61 & 4.95 \\
\hline
\end{tabular}

survival to the first crab stage was only $5 \%$ in those which were fed on Utah Artemia as compared to $63 \%$ in those which were fed on California Artemia (Tab. 3).

The larvae of the commercial blue crab, Callinectes sapidus, seemed to be less affected by Utah Artemia than other species. Fifty percent of the zoeal larvae fed on California Artemia and $31 \%$ of those fed on Utah Artemia molted into normal 
megalopa (Tab. 4). Survival to the first crab stage was $34 \%$ in those maintained on California Artemia and $24 \%$ in those fed Utah Artemia. All first crab stages were normal except one of the latter.

Table 4

Comparison of survival of Callinectes sapidus larvae fed on Artemia nauplii from California and from Utah

(Callinectes sapidus: salinity $30 \%$, temperature $25^{\circ} \mathrm{C}$ )

\begin{tabular}{|c|c|c|c|c|c|c|c|c|}
\hline $\begin{array}{l}\text { Source of } \\
\text { Artemia }\end{array}$ & Crab & $\begin{array}{l}\text { Original } \\
\text { number } \\
\text { of zoeae }\end{array}$ & $\begin{array}{l}\text { Nun } \\
\text { mes } \\
\text { norm. }\end{array}$ & $\begin{array}{l}\text { ber of } \\
\text { alopa } \\
\text { deform. }\end{array}$ & $\begin{array}{r}\mathrm{Nu} \\
\text { of } \\
\text { norm. }\end{array}$ & $\begin{array}{l}\text { mber } \\
\text { crabs } \\
\text { deform. }\end{array}$ & $\begin{array}{c}\text { Days to } \\
\text { megalopa }\end{array}$ & $\begin{array}{l}\text { Days to } \\
1 \text { st crab }\end{array}$ \\
\hline Califo & 1 & 100 & 50 & 0 & 34 & 0 & 37.35 & 9.18 \\
\hline Utah & 1 & 100 & 31 & 0 & 23 & 1 & 34.6 & 11.4 \\
\hline
\end{tabular}

The length of time for zoeae to reach the megalopal stage was approximately the same for each of the four species, whether they were fed on Utah or California Artemia larvae (See Tables 1-4).

Brine shrimp nauplii from California, when analyzed for pesticides, were found to have 2,300 ppb DDT, whereas those from Utah had 7,050 ppb DDT, or approximately three times as much DDT as the nauplii from California.

\section{DISCUSSION}

There is evidence that the difference in normality and survival of developmental stages of four species of crabs may be due to different quantities of DDT in the Artemia nauplii from California and Utah. If complete inorganic and organic analyses were made, other differences in the Artemia nauplii from the two sources might be found.

SLOBODKIN (1968) reported that Artemia eggs from Utah produced nauplii which were toxic to plaice larvae reared in Great Britain. Although he stated the toxicity of the Utah nauplii had been traced to residual insecticides from surrounding agricultural regions of the Great Salt Lake basin, he did not give any information concerning the type or amount of pesticides in the eggs or nauplii.

In this investigation the amount of DDT in Artemia from the two sources is known, but the amount of pesticide absorbed and accumulated throughout larval development of the four species of crabs is not known. Woodwell et al. (1967) have shown that there is usually an increase in concentration of DDT residues from smaller to larger organisms and from lower to higher trophic levels.

It is suggested that by the time Rhithropanopeus harrisii larvae fed on Artemia nauplii from Utah have developed to the megalopal stage they have accumulated enough DDT to cause abnormalities and to bring about paralysis and lack of coordination. There are numerous references in the literature which reveal that DDT affects the nervous system of various adult animals. WURSTER \& WINGATE (1968) reported that DDT interferes with normal calcification of the arthropod nerve axon 
and produces similar effects to those resulting from calcium deficiency. ODum et al. (1969) found that fiddler crabs (Uca pugnax) fed on detritus containing $10.0 \mathrm{ppm}$ DDT residues developed poor co-ordination on day 4 and were unco-ordinated on day 5. Lowe (1965) found that some juvenile blue crabs, Callinectes sapidus, died in $0.5 \mathrm{ppb}$ solution. These exhibited extreme irritability, increased sensitivity to external stimuli and finally paralysis before death. Although there seems to be no information on the effect of DDT on zoeae and megalopa of crabs, the behavior of $R$. barrisii megalopa fed on Utah Artemia is somewhat similar to the behavior of adult Crustacea poisoned by pesticides.

If our assumption is correct that the abnormalities, lack of coordination, and eventual death of $R$. harrisit megalopa are due to DDT poisoning, it follows that the amounts present in zoeal stages were sublethal because survival to the megalopa stage was equally high in those fed California and Utah Artemia. In Hexapanopeus angustifrons, the DDT in Artemia nauplii from Utah was lethal to both zoeal and megalopal stages for only $10 \%$ reached the megalopal stage and $2 \%$ were abnormal. None molted to the first crab stage, whereas $74 \%$ of the original number of zoeae fed on California Artemia reached the megalopal stage and $69 \%$ the first crab stage.

It is difficult to understand why the large spider crab, Libinia emarginata, which has only two zoeal stages and one megalopal stage, should be more drastically affected by Artemia from Utah. It passes through the larval stages and reaches the first crab stage in a relatively short time (12.56 to 13.58 days), as compared to the blue crab, Callinectes sapidus, which passes through seven zoeal stages and one megalopal stage (Cosroow \& Bookнout 1959) in 46.0 to 46.53 days, and presumably consumes a greater quantity of Utah Artemia than Libinia larvae. To answer this question and others, there are plans to analyze eggs and each larval stage until the first crab stage is reached to determine the amount of DDT which is absorbed and stored as development progresses.

\section{SUMMARY}

1. Four crabs, Rbithropanopeus barrisii, Hexapanopeus angustifrons, Libinia emarginata and Callinectes sapidus, were reared from the egg to the first crab stage on freshly hatched Artemia salina nauplii from two sources: salt pools in California, and the Great Salt Lake in Utah. All larvae showed better survival on California nauplii than on Utah nauplii. The crab larvae fed on California nauplii showed normal development, whereas all $R$. barrisii megalopa and some $H$. angustifrons showed a particular set of abnormalities.

2. There is evidence that the difference in normality and survival of developmental stages of the four species of crabs may be due to a difference in the quantity of DDT in Artemia nauplii from California and from Utah. There was approximately three times as much DDT in Artemia nauplii from Utah as in the nauplii from California. The nature of the abnormalities which appeared in larvae fed on Utah nauplii resembled DDT poisoning which has been reported in juvenile and adult crabs. 
Acknowledgements. The authors are indebted to Mrs. S. HERring for technical assistance and Miss G. PAYEN for help with the translation of the Abstract. These studies were supported by grant (GB-5711) from National Science Foundation.

\section{LITERATURE CITED}

Costrow, J. D., Jr. \& Bоокноuт, C. G., 1959. The larval development of Callinectes sapidus RathBun reared in the laboratory. Biol. Bull. mar. biol. Lab., Woods Hole 116, 373-396. - - 1960. A method for developing Brachyura eggs in vitro. Limnol. Oceanogr. 5, 212-225.

- - 1966. Larval development of the crab, Hexapanopeus angustifrons. Cbesapeake Sci. 7 , 148-156.

- - \& Monroe, R. J., 1966. Studies on the larval development of the crab Rbithropanopeus harrisii Gould. I. The effect of salinity and temperature on larval development. Physiol. Zool. 38, 81-100.

Kuenen, D. J., 1939. Systematical and physiological notes on the brine shrimp, Artemia. Archs néerl. Zool. 3, 365-449.

Littue, G., 1969. The larval development of the shrimp, Palaemon macrodactylus Rathbun, reared in the laboratory, and the effect of eyestalk extirpation on development. Crustaceana 17, 69-87.

LowE, J. I., 1965. Chronic exposure of blue crabs, Callinectes sapidus, to sublethal concentrations of DDT. Ecology 46, 899-900.

Odum, W. E., WoOdWell, G. M. \& Wurster, C. F., 1969. DDT residues absorbed from organic detritus by fiddler crabs. Science, N.Y. 164, 576-577.

Rollefsen, G., 1939. Artificial rearing of fry of seawater fish. Preliminary communication. Rapp. P.-v. Reun. Cons. perm. int. Explor. Mer. 109, 133.

Slobodkin, L. B., 1968. Aspects of the future of ecology. Biol. Sci., Tokyo 18, 16-23.

Woodwell, G. M., Wurster, C. F. \& IsaAcson, P. A., 1967. DDT residues in an east coast estuary: a case of biological concentration of a persistent insecticide. Science, N.Y. 156, $821-823$.

Wurster, C. F. \& WINGATE, D. B., 1968. DDT residues and declining reproduction in the Bermuda petrel. Science, N.Y. 159, 979-981.

First author's address: Dr. C. G. Bоокңочт

Duke University

Marine Laboratory

Beaufort, N.C. 28516, USA 